\title{
IMPACT OF RESIDENTIAL CARE CULTURE ON QUALITY OF LIFE OF CARE LEAVERS
}

\section{Ivan Lukšík and Lucia Hargašová}

\begin{abstract}
The quality of life of young adult residential care leavers is influenced by several factors. The impact of the residential care environment can be conceptualised as organisational culture. In our empirical study we explored how organisational culture affects the quality of life of care leavers. The research was conducted using a combination of qualitative and quantitative methods in 8 selected residential care facilities in Slovakia, and among 39 young care leavers. Data from semi-structured interviews were analysed using methods associated with grounded theory, and data obtained via questionnaires were analysed using statistical methods. The results show that adequate material conditions, adherence to facility rules, the space to act independently, responsive care, support in planning for the future, mutual assistance, and social support from peers and others are all likely to contribute to a higher quality of life for care leavers.
\end{abstract}

Keywords: residential care, quality of life, care leavers, organisational culture, substitute parenting

Acknowledgement: This research was made possible by the support of the Slovak Research and Development Agency, agreement no. APVV-0368-12, project: "Training of young people in children's homes and re-education centres: Analysis and innovation", and Slovak Research Agency VEGA, agreement no. 2/0027/17, project: "Traditional and alternative parenting in the 21st century: Motivation, dilemmas and consequences".

Ivan Lukšík PhD (the corresponding author) is a professor at the Institute for Research in Social Communication, Slovak Academy of Sciences, Dúbravská cesta 9, 84104 Bratislava, Slovakia. Email: $\underline{\text { ivan.luksik@savba.sk }}$

Lucia Hargašová $\mathrm{PhD}$ is a postdoctorate researcher at the Institute for Research in Social Communication, Slovak Academy of Sciences, Dúbravská cesta 9, 84104 Bratislava, Slovakia. Email: lucia.hargasova@savba.sk 
International Journal of Child, Youth and Family Studies (2018) 9(2): 86-108

A survey conducted by Eurochild in 30 European countries found that there are approximately one million children in alternative care (1\% of the child population; Eurochild, 2010). Experts have repeatedly questioned whether being placed in care is beneficial for the child. The concern is whether this kind of care helps children deal with the problems that accompany them into care and whether it prepares them sufficiently for later life.

Some children are placed in care to protect them from negative influences in their home environment. Such placements may arise because of poverty, pathology of the family environment (parental alcoholism or other addictions, domestic violence, neglect, or child abuse), or nonfunctioning, poor, or non-existent family support, among other reasons (Barth, Wildfire, \& Green, 2006; Our Home Association, Poland, 2008). In Slovakia in 2013, the main reason for children being placed in residential care was neglect, accounting for $55.4 \%$ of cases (Fico, 2016a). The lack of preventative work with families struggling to cope is a serious problem (Kriglerová, 2015).

Some research has indicated that residential care can have unintended consequences; for instance, children may not be sufficiently protected against violence, bullying, and abuse (Andersson, 2007; Johansson, 2007; Kendrick \& Hawthorn, 2012). Jackson (2010) lists the following problems relating to residential care: children are trained for poorly paid jobs with low hiring prospects, they have irregular school attendance and gaps in their learning, teachers and social workers have low expectations and aspirations for them, and they feel they have little control over their lives.

There is also evidence that indicates residential care can have a positive influence on children and young people (Kendrick, 2012; Shaw, 2007). For instance, the psychosocial functioning of children and young people placed in care was afterwards found to have improved (Knorth, Harder, Zandberg, \& Kendrick, 2008). Being placed in care can provide young people with a time-out, or temporary protection, when the family cannot provide adequate care (Škoviera, 2011). Group work on dynamics in closed groups can help children acquire new, more effective behavioural strategies and work through trauma and hurt (Kratochvíl, 2009).

Children placed in care often have problems that continue once they leave care. These young people are often at risk of psychosocial problems such as homelessness, delinquency, unemployment, health problems, early parenthood, and others (Eurochild, 2010; Farrugia, Greenberg, Chenn, \& Heckhausen, 2006; Festinger, 1983; Stein \& Dixon, 2007; Stein, Pinkerton, \& Kelleher, 2010). Studies conducted in Slovakia indicate difficulty finding employment, settling into the new environment, and coping with the challenges of everyday life, as well as more serious problems like addictive substance abuse and difficulty in maintaining long-term social and partner relationships (Brajerová, 2013; Lukšík, 2013). Young people who have been in care are not automatically destined for a life of failure, social exclusion, or employment difficulties (Fico, 
International Journal of Child, Youth and Family Studies (2018) 9(2): 86-108

2016b). Despite the risks, they may find their situations stabilised, especially those in supportive partnerships (Jahnukainen, 2007).

A key question is how the various models and types of care contribute to young people's quality of life once they leave residential care. There are many kinds of care: residential care, foster care, kinship care, adoption, and so on. This study looks only at residential care, specifically at the organisational culture of residential care facilities and the impact it has on post-care quality of life.

Fisher and Alford (2000) listed 164 definitions of "organisational culture". Essentialist definitions are common, such as those that view organisational culture as a set of broadly shared attitudes, values, assumptions, and norms that give rise to specific behaviours and physical manifestations, and become part of the thinking and practices of members of the organisation (Wick \& Bradshaw, 2002). Similarly, Trice and Beyer (1993) state that organisational culture is ideological in nature; that is, informed by the emotionally shared beliefs, values, and norms that drive people to perform certain activities and justify them to themselves and to others. Culture is thought of as a deeply rooted phenomenon that is omnipresent, influential, and difficult to change (Schein, 2010). Others define organisational culture more simply as established habits that form part of the everyday lives and behaviours of the employees (Bělohlávek, Košt’an, \& Šuler, 2001).

Although organisational culture has been explored in businesses and also in education (school culture), organisational culture in residential care is a peripheral, albeit not entirely unresearched, topic (Lukšík, 2012; Sekera, 2008; Pytka, 2000; Mišíková, 2008; Killett et al., 2014). Clearly, investigations of organisational culture in residential care should take account of both the normative conception - the rules and principles that help the children and young people develop; and the anthropological conception of something shared by all members of the organisation that ensures repeated behaviour patterns (Brinkmann, 2007). Škoviera and Pukančík (2012) divide the factors that shape organisational culture in residential care into 15 cultureforming spheres: the location, interior, clients, staff, structure of life, boundaries, material security, use of personal items, management policy, rules, relationships, success status, connection with the real world, language, and, lastly, traditions, rituals and symbols. A number of authors have highlighted the effect organisational culture and climate have on staff well-being and the organisation's outcomes (Carr, Schmidt, Ford, \& DeShon, 2003; Hartnell, Ou, \& Kinicki, 2011; Sackmann, 2011), including outcomes for those in the child welfare system (Glisson \& Green, 2011; Glisson \& Hemmelgarn, 1998; Glisson, Hemmelgarn, Green, \&Williams, 2013; Yoo \& Brooks, 2005).

James (2011) described various models of group care in relation to child outcomes; for example, Positive Peer Culture (transforming a negative peer context into a positive peer culture), the Teaching-Family Model (emphasising family-style living and learning, with clearly defined goals), the Sanctuary Model (creating organisational culture through a trauma-informed method), the Stop-Gap Model (breaking the youngster's downward spiral and preparing the post-discharge environment for integration), and the Re-education Model (focusing on competence and learning, 
building relations, and developing a culture of questioning and informed, or data-driven, decisionmaking through a strength-based approach and an ecological orientation). Elements with a positive effect on the lives of children in residential care include parental engagement (Jenson \& Whittaker, 1987), educational attainment (Trout, Hagaman, Casey, Reid, \& Epstein, 2008), placement stability (Ward, 2009), peer relations in care facilities (Bayer, Hjalmarsson, \& Pozen, 2009), and expected duration of treatment (Lindquist, 2011). Affirmative and supportive family relationships help children develop and maintain an interest in education and academic accomplishment (Gilligan, 2007, Jackson \& Martin, 1998, Samuels \& Pryce, 2008). Similarly Jahnukainen (2004) stated that although the risk of exclusion among residential care leavers is reduced by factors such as education and social service provision, the formation of close informal relationships outside the facility also has an important effect. In their study of care leavers in Israel, Sulimani-Aidan, Benbenishty, Dinisman, and Zeira (2013) showed that optimism, preparing for independent life whilst in residential care, and support from the mother were beneficial to the social integration of care leavers with regard to economic status, accommodation, and adjustment to military service.

The concept of quality of life was originally associated with economic and socioeconomic research and used as a population indicator in statistical analyses of large population groups. Later on it was adopted in social science and became part of public policy. The World Health Organization (WHO) quality of life definition and associated measures were used in these fields, with quality of life being defined as "the individual's perception of their position in life in the context of the culture and value systems in which they live and in relation to their goals, expectations, standards and concerns" (WHO, 1997, p. 3). "It is a broad ranging concept affected in a complex way by the person's physical health, psychological state, level of independence, social relationships, personal beliefs and their relationship to salient features of their environment" (WHO, 1997, p. 3). In her analysis of this definition, Bačová (2004) highlights the need to take account of people's social inequalities and their sources as well as the relationship between their quality of life and their value systems, goals, desires, and expectations in life. It is usual to distinguish between the objective and subjective dimensions of quality of life. The objective dimension captures the person's material sufficiency, social acceptance, and physical health. Subjective quality of life usually concerns feelings, well-being, and satisfaction (Bačová, 2008). Hartlová and Hartl (2000) defined quality of life as equivalent to happiness with life, with the most common characteristics being self-sufficiency in caring for oneself, mobility, degree of selfrealisation, and spiritual harmony - the level of life satisfaction. Research into quality of life carried out in Great Britain (Bowling, 1995) suggested several important areas that can be observed when investigating quality of life, such as relationships with family and friends, personal health and the health of loved ones, finances, accommodation, living standard, relationships, work opportunities, free time, job satisfaction, education, religion, and environment.

A study on health-related quality of life among adolescents in residential care indicated that a significant number of young people had health risks, and that gender (female) and psychotropic medication worsened the overall score (Nelson et al., 2014). Children who had been 
International Journal of Child, Youth and Family Studies (2018) 9(2): 86-108

maltreated in residential care reported a lower quality of life compared to the reference groups (Greger, Myhre, Lydersen, \& Jozefiak, 2015). However, some findings are counterintuitive. Carroll, Duffy, and Martin (2014) found that quality of life in certain groups in residential care was higher than in adolescents from mainstream schools. The highest scores were reported among children in a day-group setting, followed by children in secure placements, while children from mainstream schools came third (comparison group), and the worst results were found among the young people in the residential group. The quality of life in residential care leavers may be affected by objective difficulties relating to living conditions in areas such as accommodations (Biehal \& Wade, 1999, Wade \& Dixon, 2006), employment, education (Jackson, 2008), income, and health (Dixon, 2008); as well as by subjective satisfaction with life — self-respect, mental health, partner relations, social support, desires, expectations, and meaning of life (Dixon, 2008).

Despite displaying trends similar to those found in other European countries, residential care in Slovakia has its own particular features. In 2013 there were 14,074 children (1.4\% of the child population) being cared for outside their own families in Slovakia. Since 2000 the proportion of children being brought up in care has risen (in 2002, it was $0.99 \%$ ); however, there has been a decline in the proportion of children in residential care and a rise in the proportion in foster care (Fico, 2015). There are two main kinds of residential care in Slovakia: children's homes (CHs) and re-education centres (RCs). CHs are a type of care for children up to the age of 18 (or 25 if attending university). Placements are made on the basis of a court ruling in situations where parents do not or cannot care for the child themselves, and end once the child becomes independent or can be returned to the rehabilitated family. An RC is a special centre for children up to 18 years of age who have behavioural difficulties and long-term social issues. Placements are made on request by the child's legal representative or as a result of a court ruling. The aim is to train and educate the children, including vocational training, and for them to subsequently return to their original social environment. At the time of data collection there were 66 children's homes in Slovakia, which in 2013 provided shelter for 4,798 children. A further 1,394 children were placed with foster families under the supervision of CHs. In 2013 there were 572 children placed in 12 RCs (Fico, 2015).

There has been a strong move to deinstitutionalise residential care services in Slovakia, just as in other European countries. It is hoped that residential care will improve with the deinstitutionalisation of care and the transformation of large facilities into smaller family-type units. However, Slovakia's case shows that this may not turn out to be a panacea. The transformation policy primarily affects $\mathrm{CHs}$ and only to a much lesser degree RCs.

In comparison with other developed countries, the aftercare provided for residential care leavers in Slovakia is modest. Records are not kept on how care leavers adapt to ordinary life, whether they find work, or what their quality of life is. Residential care staff sometimes maintain contact with care leavers but this is generally on an individual basis with no systematic information available. This is despite the fact that how young people settle into ordinary life is an important criterion for assessing residential care providers on the quality of their services and their effectiveness in preparing young people for life after care. 
International Journal of Child, Youth and Family Studies (2018) 9(2): 86-108

\section{Method}

The aim of the empirical research was to ascertain the post-care quality of life in residential care leavers and how it relates to the culture of the care facility they were placed in. We concentrated on their quality of life one to two years after they had left care. The research was conducted in three stages. First we investigated the organisational culture of the eight residential care facilities in the study (five $\mathrm{CHs}$ and three RCs). Then we looked at the quality of life of care leavers from these facilities, and finally we investigated the organisational culture of the care facilities whose leavers had a higher quality of life.

To operationalise organisational culture we used the important culture-shaping elements of an organisation (Š́koviera \& Pukančík, 2012). We thus took account of both the normative side (rules) and the anthropological side (social relationships) as well as specific aspects of residential care. We investigated 10 different areas of organisational culture from various perspectives (views of the different actors in residential care) and using a variety of methods (questionnaires, interviews, observations). The 10 areas of organisational culture are: physical environment; social setting; individual privacy, and control over personal affairs and finances; care provided to children by staff; daily routine, social boundaries, and norms; contact with the outside (family, friends); social relationships (formal and informal, close relationships); conflicts and conflict resolution; stress management and coping with difficulties; and preparations for leaving residential care.

In stage two we ascertained quality of life among young residential care leavers. Since quality of life can relate to positive life values (Bačová, 2004), we included questions about young people's value preferences in the interviews as well as general questions.

In the third stage of the research we again investigated the components of the organisational culture of the facility, comparing the facilities where care leavers had a higher quality of life with those where care leavers had a poorer quality of life in order to identify the characteristics of the better facilities.

\section{Research Method and Sample}

To research organisational culture we used a combined qualitative and quantitative methodology and several methods (observation, interview, questionnaire). We used triangulation of methods and triangulation of respondents to ensure validity of results. The research methods were observations (a researcher spent several days at the facility; filled out structured record sheets and noted down his or her open comments), semi-structured interviews, and anonymous questionnaires assessing satisfaction with the various aspects of organisational culture.

In a total of eight facilities — three RCs and five $\mathrm{CHs}$ - we interviewed 34 prospective care leavers, nine directors or deputy directors, 14 carers, five social workers, six psychologists, and two teachers. We also obtained 104 completed questionnaires from young adults and 95 from 
carers and directors or deputy directors on satisfaction with the organisation's culture (10 basic areas were specified in greater detail and broken down into 33 items, such as food, accommodation, health, free time, peer relations, and leaving preparations). In the interviews we asked the young adults about the 10 areas of organisational culture with the aim of deepening our knowledge of the facility, the young adults, and their preparations for leaving care. To enhance the validity by triangulating the sources we also interviewed other actors (carers, directors, psychologists, etc.) about the organisational culture of the residential care facility. The observations relating to these areas covered physical environment, social environment, contact with external environment, activities, rituals, and rules and regulations.

The second stage of the research involved 39 residential care leavers who had spent at least one year in the care facility where we conducted the research and who had been out of care for at least one year. We contacted the care leavers using information obtained from the care facility and the snowball method. The research methods used were interviews (27 participants) and group discussions (12 participants). The research focused on their recollections of life in the care centre, their preparations for leaving, and events occurring immediately after departure, and finally looked at the nature and quality of their current life, which was the subject of our analysis.

The research was conducted by five researchers who had multiple previous experiences of performing similar research. The interviews were held once informed consent had been obtained and after stressing that participation was voluntary and anonymous, and that the interview would take place in a private area of the facility. The research was conducted face-to-face and by telephone. Once the researchers had established rapport with the young person they freely moved on to topics and questions, whilst making an effort to keep the conversation natural and giving the young people space to freely express themselves.

The research was conducted once informed consent had been obtained from the facility director, acting as the legal representative of the boys and girls, and also from all those participating in the research. In Slovakia, there is no requirement to obtain permission from an ethics commission; nonetheless, we proceeded in accordance with the Code of Ethics issued by the Slovak Academy of Sciences.

\section{Method of Analysis}

The interviews and discussions from the first and second research stages were recorded and transcribed verbatim. The observation notes were written out. The analysis was conducted using grounded theory methods devised by Strauss and Corbin (1999): open coding and the constant comparative method (Strauss, 1987) with the help of the ATLAS.ti software. In the first step of the analysis of organisational culture, 88 categories were identified through open coding, including trust, information, contact with a social worker, departure preparations, rules contravention, rituals and celebrations, suggested care improvements, difficult life situations, and so on. In the second step of the analysis, seven categories were obtained: physical and material environment; social relationships; organisational rules, methods, and rituals; care and education; 
International Journal of Child, Youth and Family Studies (2018) 9(2): 86-108

contact with home environment; conditions for self-realisation; and borderline situations and solutions.

Data from the satisfaction questionnaire were processed using standard statistical methods and SPSS. The open coding of the care leavers' responses produced 44 codes, including, for example: future, plans, accommodation, having a child, important events, values, reasons for being in care, and finances. In the second stage of the analysis 11 categories were obtained: accommodation, finances, work, free time, education, worries and fears, enjoyment of life, satisfaction with life, important positive values, and difficult life situations, both resolved and unresolved. During the analysis a new category emerged, which we labelled "competences for handling life situations". Subsequently, the young people's views of these areas were categorised as positive or negative. Quality of life was then generated from the total positive scores minus the negative ones in the 12 categories listed above.

\section{Results}

\section{Quantitative Analysis of Organisational Culture}

In the first stage, the quantitative analysis, we analysed how the young adults and carers in the facilities viewed the organisational culture in terms of satisfaction with its various aspects, measured on a Likert scale ranging from 1 (excellent) to 5 (inadequate). The results are presented separately for the five $\mathrm{CHs}$ and the three RCs; for both analyses, a Mann-Whitney test was done $(p \leq .001)$.

Children's homes: The quantitative analysis of satisfaction among the young people and carers with various aspects of life in $\mathrm{CHs}$ found a high level of satisfaction in both groups with the following categories: accommodation (young adults: $\bar{x}=1.69, S D=0.86$; carers: $\bar{x}=1.42, S D=$ 0.66 ), education (young adults: $\bar{x}=1.71, S D=1.02$; carers: $\bar{x}=1.61, S D=0.76$ ), information about life outside the facility (young adults: $\bar{x}=1.80, S D=1.13$; carers: $\bar{x}=1.73, S D=0.64$ ) and fostering independence (young adults: $\bar{x}=1.80, S D=0.99$; carers: $\bar{x}=1.59, S D=0.70$ ). Lower levels of satisfaction were found for the system of rewards and punishments (young adults: $\bar{x}=$ 2.67, $S D=1.53$; carers: $\bar{x}=2.16, S D=0.79$ ), the system for working with children (young adults: $\bar{x}=2.42, S D=1.38$; carers: $\bar{x}=2.06, S D=0.78$ ), and the possibility of using specialist services outside the facility (young adults: $\bar{x}=1.69, S D=1.31$; carers: $\bar{x}=2.26, S D=1.34$ ).

In a number of areas, though, satisfaction levels varied between the young adults and the carers in CHs. The greatest differences (Mann-Whitney U test, $p \leq .001$ ) were that, compared to the carers, the young adults expressed greater satisfaction with progress made whilst in care, with peer relations in and outside the care facility, and with the possibility of using specialist services outside the care facility. But the young adults were less satisfied with clothing, finances, health care, carers helping solve problems, contact allowed with family, and fulfilment of religious needs. 
International Journal of Child, Youth and Family Studies (2018) 9(2): 86-108

Re-education centres: The quantitative analysis of satisfaction of the young people and carers with aspects of life in the RCs showed high rates of satisfaction in both groups regarding the following areas: physical health (young adults: $\bar{x}=2.05, S D=1.101$; carers: $\bar{x}=2.00, S D=$ 0.86 ), exercise opportunities (young adults: $\bar{x}=2.11, S D=1.132$; carers: $\bar{x}=1.93, S D=0.90$ ), carers helping solve problems (young adults: $\overline{\mathrm{x}}=2.16, S D=1.19$; carers: $\bar{x}=1.89, S D=0.685$ ), and system of working with children in the centre (young adults: $\bar{x}=2.18, S D=0.940$; carers: $\bar{x}=$ $2.18, S D=0.86)$.

Low levels of satisfaction were found in relation to food (young adults: $\bar{x}=2.98, S D=$ 1.40; carers: $\bar{x}=2.57, S D=0.93$ ), fulfilment of religious needs (young adults: $\bar{x}=2.82, S D=1.27$; carers: $\bar{x}=2.56, S D=0.93$ ), accommodation (young adults: $\bar{x}=2.77, S D=1.33$; carers: $\bar{x}=2.79$, $S D=0.957$ ), and possibilities for contact with specialists outside the centre (young adults: $\bar{x}=$ 2.53, $S D=1.123$; carers: $\bar{x}=2.87, S D=0.96$ ).

In a number of areas, though, satisfaction levels in RCs varied between the young adults and the carers. The greatest differences (Mann-Whitney $\mathrm{U}$ test, $p \leq .001$ ) were higher satisfaction rates in the young adults than the carers on progress made whilst in care, peer relations in and outside the care centre, family relations, and preparations for leaving care. By contrast the young adults were less satisfied with the system of rewards and punishment and with relations with carers.

\section{Qualitative Analysis of Organisational Culture}

The content analysis of seven categories produced the following findings:

- Physical and material environment were not important. They were generally substantially better than the children's home environments, especially in CHs; in RCs, however, there was a low level of satisfaction with the food.

- Social relations with the carers were positive: most of the children had someone close to them in the facility, especially in CHs. Carer attitudes to Roma children and prejudice about their roots was a problem in $\mathrm{CHs}$.

- Rules were a critical part of the organisational culture. There were problems concerning the levels of trust among the children and young people regarding the handling of personal information. In $\mathrm{CHs}$, the fact that life was conducted in small family groups acted as a barrier to the development of wider social contact and cohesion in the facility as a whole, especially with regard to the setting of rewards and punishments and the young people's involvement in this. Also, in CHs, the provision of care suffered from an excess of bureaucracy to the detriment of one-toone work between carer and child.

- The main aims in the care facilities were to ensure that the children's and young people's basic needs were met, that they were healthy, and to stress the importance of finishing school and the need to prepare for life after care. In CHs, overly attentive care, in which the children were "handed everything on a silver platter", discouraged 
International Journal of Child, Youth and Family Studies (2018) 9(2): 86-108

them from developing their independence and a sense of humility. An excessive focus on discipline in some $\mathrm{CHs}$ ran counter to the expected family atmosphere. The education the children and young people obtained did not always provide them with good employment prospects.

- Care was taken in the facilities to ensure that the children and young people had contact with their original family but, in general, relations between them did not improve greatly. There was capacity for making it easier for children and young people to have contact with specialists and organisations outside the facilities to help them prepare for life after care.

- The children and young people generally felt that the carers encouraged them to be independent when seeing to their basic needs such as food and clothing.

- The facilities also had borderline cases where children and young people came into contact with drugs, bullying, and racism.

\section{Quality of Life and Competencies in Residential Care Leavers}

The first year after leaving care was characterised by change: moving between different kinds of accommodation, with periods of employment and periods of being out of work with no income. The quality of accommodation depended on the young person's financial situation, which could have been improved by learning about finances and planning the next steps whilst still in care - savings, careful management, social support, and so forth. Family, acquaintances, siblings, friends, non-profit organisations, charities, and carers could all significantly help care leavers deal with their situations. Young adults faced problems finding work locally. Some resolved this by travelling to other regions or going abroad. Even after surviving the initial period of upheaval, some said they still worried about their future financial security, maintaining their jobs, their ability to finish school, and whether they would be able to bring up their own children. The values that were important to them were family, a support system and stability, and to help people close to them. Some care leavers expressed dissatisfaction with their level of education and had aspirations to study in the near future.

We used 12 areas to determine quality of life scores. In our interview transcripts we identified positive and negative experiences in each area for each participant and then allocated a plus or a minus point for each qualitative answer. The sample of 34 care leavers was then ranked from highest to lowest quality of life using these total scores for the 12 areas. This analysis showed that two facilities had care leavers with high quality of life scores. The positive scores related mainly to satisfaction with accommodation, work, free-time opportunities, and being able to resolve difficult life situations. Their responses provided more examples of a good life than those of other participants.

Care leavers who reported a better quality of life (11 out of the total research sample of 34 young adults) stood out in terms of several skills and competencies. They reported being able to: form, maintain, and sustain a relationship with a partner; take joy in everyday life; improve their 
International Journal of Child, Youth and Family Studies (2018) 9(2): 86-108

living conditions; pursue hobbies; support a household and family financially while staying within the law; help other children from the care facility; and cope with loneliness after leaving care. Moreover, these young adults described having a sense of belonging, team spirit, responsibility, caution, determination, and emotional stability; they had decided not to break off supportive relationships with care staff.

\section{Culture of Residential Care Facilities where Young People had a Higher Quality of Life}

Once we had identified care leavers with higher quality of life scores, the next step was to analyse the organisational culture of the care facility they had spent time in - one $\mathrm{CH}$ and one $\mathrm{RC}$. The characteristics of these facilities are described in the following paragraphs.

Physical and material environment: These facilities were clean and tidy (RC) and had better equipped living areas $(\mathrm{CH})$. The young people chose the equipment $(\mathrm{CH})$ and had their own personal items, such as music, toiletries, clothes, and toys $(\mathrm{CH}, \mathrm{RC})$; they had opportunities to earn money and manage their own finances $(\mathrm{CH})$.

Social relationships: It was deemed important that each young person have the support of at least one person in the care facility and one outside the care facility, and that the children mutually support and assist one another (more in the $\mathrm{CH}$, less in the $\mathrm{RC}$ ). Relationships between the children were based on mutual trust $(\mathrm{RC}, \mathrm{CH})$ and affection $(\mathrm{CH})$, and they formed relationships with people outside the facility that were not weighed down with negative experiences (RC). They valued the carers' professional but human approach (RC).

Organisation rules, methods, and rituals: The facilities stated that all rules were to be respected and that distinctions were not made on an ethnic or racial basis. The established rules were subject to regular revision, and placed clear expectations on children and staff alike (RC). There was potential for the children to be more involved in creating the rules $(\mathrm{RC}, \mathrm{CH})$. The young adults were critical of the shared responsibility rule $(\mathrm{RC})$ - a rule imposing group sanctions for non-compliance by an individual. Turnover of care staff sometimes led to problems with adherence to rules $(\mathrm{CH})$. Many children were not used to rules and daily routines in their previous lives and only gradually became used to them $(\mathrm{CH})$. Regular group meetings were held on a daily, weekly, or monthly basis for different purposes. These included welcoming or bidding farewell to residents, sharing news and providing updates on progress in education and behaviour, publicising events, and discussing the rota. Carers operated from the principle that "boredom is the source of bad behaviour" (RC). Compulsory duties for the young adults included gardening, helping in the kitchen, and cleaning (RC), and children were encouraged to perform these duties as well (RC).

Care and education: The emphasis in care was on completing education ( $\mathrm{RC})$, treating the young adults as adults rather than as children, and providing them with the space to act independently (RC). Efforts were made to perform the functions of a family (RC), to operate as a family $(\mathrm{CH})$, and to develop loving relationships to compensate for any lack of parental love $(\mathrm{CH})$. Showing an interest, respecting the child, and providing help and advice were more important than 
International Journal of Child, Youth and Family Studies (2018) 9(2): 86-108

meting out punishments and bad marks. The care regime involved turning negative thinking and behaviour into positive thinking and behaviour (RC), improving communication with close family relations and friends where relationships are difficult, making realistic plans for the future, and preparing to leave care ( $\mathrm{RC}$ and $\mathrm{CH})$. Conditions were in place for the young people to talk through their problems with carers, including intimacy-related concerns ( $\mathrm{RC}$ and $\mathrm{CH}$ ). Experts were invited to the facilities to give talks on topics such as drugs and HIV/AIDS (RC, $\mathrm{CH}$ ). A number of leisure activities were on offer (especially RC). Sessions with a psychologist were compulsory, and the young adults had conflicting views on this (RC). Personal occasions were celebrated semiformally, for example, with a cake and a song organised by the staff and children of the facility (RC); or informally by the young adults, who would decide for themselves whether and how to celebrate the event, often in flat units without staff $(\mathrm{CH})$. The carers and teachers did not see their work as just another job, but went beyond their duties to help the children (RC). However, they felt that the administrative burden of their work was increasing, and creating a barrier to caring for the children $(\mathrm{CH})$.

Although improvements could have been made in the area of education (e.g., by expanding the limited number of subjects on offer to improve employment prospects), it is important to note that positive attitudes to education were encouraged (RC), that the young people had the motivation to finish school $(\mathrm{RC})$, that they received assistance when preparing for school $(\mathrm{CH})$, and that they viewed education as a means of having a better life in the future $(\mathrm{CH})$. Various staff members assisted the young adults with their preparations for leaving care $(\mathrm{CH}$ and $\mathrm{RC})$.

Contact with their social environment: The facilities provided general support for the children to maintain contact with their biological families $(\mathrm{CH}, \mathrm{RC})$. Young adults could also maintain contact with peers outside the facilities with the carers' consent $(\mathrm{CH})$.

Conditions for self-realisation: The children and young adults could pursue leisure activities (sport, reading, looking after animals), and this is seen as a means of escape from everyday routine $(\mathrm{CH}, \mathrm{RC})$. The young adults also had opportunities to earn money $(\mathrm{CH})$.

Borderline situations and solutions: When conflicts and borderline situations occurred $(\mathrm{CH}, \mathrm{RC})$, they were resolved on the spot, then considered again later at the evening meeting (RC).

\section{Discussion and Conclusion}

The research has shown that it is not possible to form an entirely uniform view of organisational culture in these selected care facilities. Differences were found between the organisational cultures of the $\mathrm{CHs}$ and RCs and in the way they were perceived by the children and young adults and the staff.

For aspects of the organisational culture in $\mathrm{CHs}$, positive agreement between residents and staff was found in relation to meeting the resident's basic needs (e.g., food, housing, clothing), trying to maintain an optimal standard of living, the emphasis on education, the information 
supplied about life after care and encouragement to become independent, and the importance of having close relationships in the facility and contact with the original family. In the RCs there was also positive agreement that the children's basic needs were met; however, here this referred more to health and exercise. In terms of the social and educational side in the RCs, important aspects were: carers helping the children solve problems, the system of working with the children, and contact with the original family. Also, some importance was attached to preparations for leaving care and the support given to children and young people to satisfy their ordinary needs.

Problem areas in the CHs that the actors agreed on were: the treatment of Roma children, children being isolated in small groups and lacking a sense of belonging and solidarity with the other children, staff doing too much for the children, an excessive focus on discipline, weak progression in family relations, the organisational rules being too strict, issues of trust between the carers (particularly psychologists) and the children, and opportunities to have contact with specialists outside the facility. Problem areas in the RCs were: the standard of living, the fulfilment of religious needs, opportunities to have contact with specialists outside the centre, the complexity and inflexibility of the organisational rules, and issues of trust between the carers (particularly psychologists) and the children.

Although having a positive relationship with the original family (Jenson \& Whittaker, 1987) and other positive social bonds (Jahnukainen, 2004) are considered important factors in preparing for independent life, in the facilities investigated in this research, developing positive family relationships had proved difficult and only peer relations were viewed positively by the young adults. Schooling and educational attainment, which have been shown to be key aspects of preparing for future life (Jahnukainen, 2004; Trout et al., 2008) were only emphasised in the CHs in our research.

One interesting finding was that the young adults, in both the $\mathrm{CHs}$ and the $\mathrm{RCs}$, expressed greater optimism about the progress they achieved whilst in care and about their peer relations in and outside the facility than did the carers. The young adults in the $\mathrm{CHs}$ were also more optimistic about the use of specialist services outside the facility, and the young adults in the RCs viewed their relationships with their families more positively than staff did. This finding suggests there is hope of a successful outcome for young people leaving care, as the experiences of leavers with a better quality of life suggest that optimism and hope contribute to a higher quality of life. Equally, though, the divergent views of the carers and children on this may indicate that the children have a less realistic view of their lives now and in the future. Sulimani-Aidan et al. (2013) pointed out that other studies have shown that optimism and being prepared for independent life are also important for the social and workplace inclusion of residential care leavers. Given this finding, we can question whether supporting optimism among children might better prepare them for life after care than a policy of teaching them to plan their futures more cautiously.

Our research shows that coping well with the transitional first year after leaving care was important for quality of life. We recorded indications that care leavers experienced fluctuations 
and sought stability in the three linked areas of work, finances, and accommodation. Supportive relationships, an ability to focus on positive values, determination, and being content with modest conditions all feed into the enjoyment of everyday life among care leavers. The main elements of residential care that promote future quality of life mentioned by care leavers were preparing for departure whilst still in care and continuing support from staff. Care leavers who reported a better quality of life overall did not generally have better financial situations but were better able than other participants to deal with difficult life situations. One explanation for this may be the use of cognitive mechanisms and affective components in assessing quality of life, which enables a person to experience personal well-being despite adverse living circumstances (Džuka, 2004).

The research shows that young people placed in some facilities (which we shall call type Q) had better post-care quality of life than others, and that these facilities had some special characteristics. Non-type Q CHs were physically and materially equipped to the same standard. Problems with the food and accommodation were identified in RCs. We found that conditions were similar in type Q facilities but that the young people in them were additionally able to make their own decisions, had their own personal items, and, in CHs, they could earn money and manage their own finances.

In terms of social relationships the facilities were generally careful to ensure all residents had at least one person to whom they were close, and this was especially the case in CHs. In type $\mathrm{Q}$ facilities we also found that the relationships between children were built on trust, that the carers adopted a professional and human approach, and that important relationships were established with people from "outside" who had different life experiences. These are key characteristics of the Positive Peer Culture model (James, 2011); however, the model has not so far been implemented systematically across the board in Slovak care facilities.

The organisational rules of the facilities were generally criticised. In type Q facilities it was stated that all actors had to respect the rules. Staff members in these facilities were ethnically sensitive in contrast to the attitudes to Roma children that are widespread in residential facilities in Slovakia; this is not conscious discrimination but clear distinctions are made between Roma children and others, both implicitly and symbolically in everyday practice (Kriglerová, 2015). Type Q facilities also had established rules but they were regularly reviewed and the children and young adults had some say in this. The rules were learned gradually during the initial transitional stage of the placement. In type Q facilities there were regular social, work, and leisure gatherings.

In non-type $\mathrm{Q}$ facilities children expressed dissatisfaction with the system of care. The system was aimed at ensuring the children's needs were met and that they were educated. We also found both restrictive and excessive approaches to care. In type $\mathrm{Q}$ facilities attempts were made to emulate the family and also to develop loving relationships. In these facilities relations with the young people were based on partnerships, and the approach was more appreciative than restrictive. The young adults took up opportunities to confide in someone and were able to have contact with specialists who visited the facility. The staff paid attention to preparing the young people for their 
International Journal of Child, Youth and Family Studies (2018) 9(2): 86-108

future lives. Although the quality of the education was a problem in these facilities, support for pursuing an education was deemed important. In both $\mathrm{Q}$ and non-Q type facilities, contact with the biological family was encouraged; however, progress in forging better relations between the children and family members was poor. In the type Q $\mathrm{CH}$, contact with peers outside the home was supported.

In non-type $\mathrm{Q}$ facilities young people did have free time to themselves but they often spent it attending to their basic needs (clothing, personal care, etc.) In type $Q$ facilities free time was accorded greater importance and seen as a means of escape from everyday life (e.g., hobbies, sports, spending time with people outside of the facility). In one of these facilities young people were able to earn extra money during their free time. In both types of facility there were also situations involving drugs, bullying, and racism. In type $Q$ facilities a system had been set up to deal with conflicts and problem situations.

These findings are similar to those of Škoviera (2014): in order to improve the quality of the organisational culture and its effect on children and young people, one has to look at the way life is organised in the facility because it is accepted and internalised by the children and forms the basis upon which they organise their own lives and come to respect social norms. Traditions, rituals, and symbols create order in life and also provide experiences that are a break from the ordinary and connect the facility to real life.

Our findings underline the importance of two elements of residential care that are associated with resilience and social inclusion (Ungar, 2005): regular schooling and recognising that education is the best path to a better life. Other important elements are contact with more successful peers, developing interests and hobbies to improve young people's social skills and bring them into contact with a wider range of people outside the family and school environments, and meeting important adults who can offer support and encouragement and who model certain behaviours.

\section{Limitations}

This study has a number of limitations. One of the most serious is the fact that it is very hard to establish a clear causal effect between organisational culture and quality of life once the individual has left a particular facility. Quality of life in young adults leaving a facility can be affected by a number of other factors including the influence of the original family setting, the influence of people important to that person, access to resources, and so on. We presume that quality of life is higher in care leavers who are contactable than in those who are hard to reach. There is also a time-lag problem. We investigated the care facilities one year after discharge and changes could have occurred during that time. We attempted to overcome the time lag by comparing the views of care leavers with those still in care. Further longitudinal research could produce more detailed findings. 
International Journal of Child, Youth and Family Studies (2018) 9(2): 86-108

\section{Conclusion}

The results indicate that a number of factors in the organisational culture of a facility can contribute to quality of life among care leavers. It is important that emphasis should be placed on: finishing education, providing room for independent action, adopting an accommodating approach to care that can substitute for parental love, encouraging positive thinking, fostering better relationships with the original family, encouraging promising social ties, promoting planning for the future, developing mutual assistance and support between the children in the facility, and encouraging hobbies and ways of earning money so that the young people can gradually "arrange" their own lives whilst still in care. It is also important that no ethnic or racial distinctions are made in the facility and that conditions are in place for the children and young people to talk through their problems. Ensuring that the facility has the appropriate material conditions and that everybody respects the rules is also important. 
International Journal of Child, Youth and Family Studies (2018) 9(2): 86-108

\section{References}

Andersson, B. (2007). Diversity in residential care and treatment for young people in Sweden (Doctoral dissertation). University of Gothenburg, Gothenburg, Sweden.

Bačová, V. (2004). Kvalita žvota, hodnotové systémy v spoločnosti a sociálny kapitál. K vymedzeniu psychologických dimenzií kvality života[Life quality, value systems in society and social capital. On the delimitation of psychological dimensions of life quality]. In J. Džuka, (Ed.), Psychologické dimenzie kvality života [Psychological dimensions of life quality] (pp. 9-13). Prešov, Slovakia: Prešov University.

Bačová, V. (Ed.). (2008). Kvalita života a sociálny kapitál [Quality of life and social capital]. Prešov, Slovakia: FilF PU.

Barth, R. P., Wildfire, J., \& Green, R. L. (2006). Placement into foster care and the interplay of urbanicity, child behaviour problems, and poverty. American Journal of Orthopsychiatry, 76(3), 358-366. doi:10.1037/0002-9432.76.3.358

Bayer, P., Hjalmarsson, R., \& Pozen, D. (2009). Building criminal capital behind bars: Peer effects in juvenile corrections. Quarterly Journal of Economics, 124(1), 105-147. doi:10.1162/qjec.2009.124.1.105

Bělohlávek, F., Košt’an, P., \& Šuler, O. (2001). Management. Olomouc, Czech Republic: Rubico.

Biehal, N., \& Wade, J. (1999). "I thought it would be easier" The early housing careers of young people leaving care. In: J. Rugg (Ed.),Young people, housing, and social policy (pp. 79-92). London, UK: Routledge.

Bowling, A. (1995). What things are important in people's lives? A survey of the public's judgements to inform scales of health related quality of life. Social Science and Medicine, 41, 1447-1462. doi:10.1016/0277-9536(95)00113-L

Brajerová, L'. (2013). Náhradná výchovná starostlivost’ a process osamostatňovania sa adolescentov [Care and the process of becoming independent in adolescents] (Doctoral dissertation). Constantine the Philosopher University of Nitra, Nitra, Slovakia.

Brinkmann, S. (2007). Culture as practices: A pragmatist conception. Journal of Theoretical and Philosophical Psychology, 27, 192-212. doi:10.1037/h0091293

Carr, J. Z., Schmidt, A. M., Ford, J. K., \& DeShon, R. P. (2003). Climate perceptions matter: Ameta-analytic path analysis relating molar climate, cognitive and affective states, and individual level work outcomes. Journal of Applied Psychology, 88 (4), 605-619. doi:10.1037/0021-9010.88.4.605 
International Journal of Child, Youth and Family Studies (2018) 9(2): 86-108

Carroll, D., Duffy, T., \& Martin, C. R. (2014). A comparison of the quality of life of vulnerable young males with severe emotional and behaviour difficulties in a residential setting and young males in mainstream schooling. Journal of Psychiatric and Mental Health Nursing, 21(1), 23-30. doi:10.1111/jpm.12042

Dixon, J. (2008). Young people leaving care: health, well-being and outcomes. Child \& Family Social Work, 13(2), 207-217. doi:10.1111/j.1365-2206.2007.00538.x

Džuka, J. (2004). Kvalita života a subjektívna pohoda - teórie a modely, podobnost' a rozdiely [Life quality and subjective well-being - Theories and models, similarities and differences]. In J. Džuka, (Ed.), Psychologické dimenzie kvality života [Psychological dimensions of life quality] (pp. 42-63). Prešov, Slovakia: Prešov University.

Eurochild. (2010). Children in alternative care - National surveys (2nd ed.). Brussels, Belgium: Author.

Farrugia, S. P., Greenberg, E., Chenn, C. S. \& Heckhausen, J. (2006). Perceived social environment and adolescents' well-being and adjustment: Comparing a foster care sample with matched sample. Journal of Youth and Adolescence, 35(3), 349 - 358. doi:10.1007/s10964-006-9029-6

Festinger, T. (1983). No one ever asked us: A postscript to forever care. New York, NY: Columbia University Press.

Fico, M. (2015). Deti vyrastajúce mimo vlastnej rodiny: vývojové trendy a súvislosti.[Children growing up outside their families: Developmental trends and contexts]. Unpublished manuscript.

Fico, M. (2016a). Determinanty pracovného uplatnenia mladých l'udí po odchode z náhradnej inštitucionálnej starostlivosti [Determinants of the employability of care leavers] (Doctoral dissertation). Comenius University, Bratislava, Slovakia.

Fico, M. (2016b). Ne/zamestnanost' po odchode z detských domovov [(Un)employment after leaving children homes]. In L. Hargašová (Ed.), Zo zariadenia do samostatného života: Inovácie ústavnej starostlivosti a kvalita života po odchode zo zariadenia [From facilty to independent life. Innovations in residential care and quality of life after leaving care] (pp. 89 -110). Conference proceedings of the Faculty of Education, University of Trnava, Trnava, Slovakia.

Fisher, C. J. \& Alford, R. J. (2000). Consulting on culture: A new bottom line. Consulting Psychology Journal: Practice and Research, 52(3), 206-217. doi:10.1037/1061$\underline{4087.52 .3 .206}$ 
International Journal of Child, Youth and Family Studies (2018) 9(2): 86-108

Gilligan, R. (2007). Adversity, resilience and the educational progress of young people in public care. Emotional and Behavioural Difficulties, 12(2), 135-145. doi:10.1080/13632750701315631

Glisson, C., \& Green, P. (2011). Organizational climate, services, and outcomes in child welfare systems. Child Abuse \& Neglect, 35(8), 582-591. doi:10.1016/j.chiabu.2011.04.009

Glisson, C., \& Hemmelgarn, A. (1998). The effects of organizational climate and interorganizational coordination on the quality and outcomes of children's service systems. Child Abuse \& Neglect, 22(5), 401-421. doi:10.1016/S0145-2134(98)00005-2

Glisson, C., Hemmelgarn, A., Green, P., \& Williams, N. J. (2013). Randomized trial of the Availability, Responsiveness and Continuity (ARC) organizational intervention for improving youth outcomes in community mental health programs. Journal of the American Academy of Child and Adolescent Psychiatry, 52(5), 493-500. doi:10.1016/j.jaac.2013.02.005

Greger, H. K., Myhre, A. K., Lydersen, S., \& Jozefiak, T. (2015). Previous maltreatment and present mental health in a high-risk adolescent population. Child Abuse and Neglect, 45, 122-134. doi: 10.1016/j.chiabu.2015.05.003

Hartlová, H., \& Hartl, P. (2000). Psychologický slovník [A dictionary of psychology]. Prague, Czech Republic: Portál.

Hartnell, C. A., Ou, A. Y., \& Kinicki, A. (2011). Organizational culture and organizational effectiveness: Ameta-analytic investigation of the competing values framework theoretical suppositions. Journal of Applied Psychology, 96(4), 677-694. doi:10.1037/a0021987

Jackson, S. (2008). Careleavers, exclusion and access to higher education. In D. Abram, J. Christie, \& D. Gordan (Eds.), Multidisciplinary handbook of social exclusion research (pp. 115-136). Chichester, UK: Wiley.

Jackson, S. (2010). Moving on from care, staying in education, new findings from the YIPPEE project. In "I matter": Preparation for independent living (Briefing paper 2, pp.4-7). Innsbruck, Austria: SOS Children s Villages International.

Jackson, S., \& Martin, P. Y. (1998). Surviving the care system: Education and resilience. Journal of Adolescence, 21(5), 565-583. doi:10.1006/jado.1998.0178

Jahnukainen, M. (2004) Education in the prevention of social exclusion. The Review of Disability Studies, 1(3), 36-44.

Jahnukainen, M. (2007). High-risk youth transitions to adulthood: A longitudinal view of youth leaving the residential education in Finland. Children and Youth Services Review, 29, 637654. doi:10.1016/j.childyouth.2007.01.009 
International Journal of Child, Youth and Family Studies (2018) 9(2): 86-108

James, S. (2011). What works in group care? A structured review of treatment models for group homes and residential care. Children and Youth Services Review, 33(2), 308-321. doi:10.1016/j.childyouth.2010.09.014

Jenson, J. M., \& Whittaker, J. K. (1987) Parental involvement in children's residential treatment: From preplacement to aftercare. Children and Youth Services Review, 9(2):81-100. doi:10.1016/0190-7409(87)90011-9

Johansson, J. (2007). Residential care for young people in Sweden: Homes, staff and residence (Doctoral dissertation). University of Gothenburg, Gothenburg, Sweden.

Kendrick, A. (2012). What research tells us about residential child care. In M. Davies (Ed.), Social work with children and families (pp. 287-303). Basingstoke, UK: Palgrave Macmillan.

Kendrick, A., \& Hawthorn, M. (2012). National confidential forum for adult survivors of childhood abuse in care: Scoping project on children in care in Scotland,1930 - 2005. Glasgow, UK: Centre for excellence for looked after children in Scotland \& Scottish Institute for Residential Child Care. Retrieved from https://www.celcis.org/files/1614/3878/5242/Confidential-Forum-Adult-Survivorschildhood-Abuse-v2.pdf

Killett, A., Burns, D., Kelly, F., Brooker, D., Bowes, A., La Fontaine, J., ... O’Neill, M. (2014). Digging deep: How organisational culture affects care home residents' experiences. Ageing and Society, 36(1), 160-188. doi:10.1017/S0144686X14001111

Knorth, E. J., Harder, A. T., Zandberg, T., \& Kendrick, A. J. (2008). Under one roof: A review and selective meta-analysis on the outcomes of residential child and youth care. Children and Youth Services Review, 30(2), 123-140. doi:10.1016/j.childyouth.2007.09.001

Kratochvíl, S. (2009). Skupinová psychoterapia v praxi [Group psychotherapy in practice]. Prague, Czech Republic: Galén.

Kriglerová, E. (Ed.) (2015). Štátne deti na jednej lodi? Rómske deti v detských domovoch [State children all in one boat? Roma children in children homes]. Bratislava, Slovakia: CVEK.

Lindqvist, E. (2011). Planned treatment and outcomes in residential youth care: Evidence from Sweden. Children and Youth Services Review, 33(1), 21-27. doi:10.1016/j.childyouth.2010.08.007

Lukšík, I. (Ed.). (2012). Kultúra škôl a výchovných zariadení [School culture and culture of residential care facilities]. Bratislava, Slovakia: Comenius University. 
International Journal of Child, Youth and Family Studies (2018) 9(2): 86-108

Lukšík, I. (2013). Životné dráhy mladých l'udí po odchode z reedukačných centier - stratégie zvládania t’ažkých životných situácií, správa [Life paths of young people after leaving reeducation centers - coping strategies for difficult life situations]. Bratislava, Slovakia: Iuventa.

Mišíková, J. (2008). Komunitní systém v resocializačních zařízeních pro adolescenty [Community system in resocialisation centres for adolescents]. Ostrava, Czech Republic: Pedagogical Faculty, University of Ostrava.

Nelson, T. D., Kidwell, K. M., Hoffman, S., Trout, A. L., Epstein, M. H., \& Thompson, R. W. (2014). Health-related quality of life among adolescents in residential care: Description and correlates. American Journal of Orthopsychiatry, 84(3), 226-233. doi:10.1037/h0099812

Our Home Association, Poland. (2008). The child's right to a family: Foster care under the lens (JLS/2008/FRAC/AG/1419). Milan, Italy: Amici dei Bambini (AiBi). Retrieved from http://www.synergia-net.it/uploads/attachment/foster_care_pol_1327588517.pdf

Pytka, L. (2000). Pedagogika resocjalizacyjna [Pedagogy of resocialization]. Warsaw, Poland: Wydawnictwo Akademii Pedagogiki Specjalnej.

Sackmann, S. A. (2011). Culture and performance. In N. M. Ashkanasy, C. P. M. Wilderom, \& M. F. Peterson (Eds.), The handbook of organizational culture and climate (2nd ed., pp. 188-224). Thousand Oaks, CA: Sage.

Samuels, G. M., \& Pryce, J. M. (2008). "What doesn't kill you makes you stronger": Survivalist self-reliance as resilience and risk among young adults aging out of foster care. Children and Youth Services Review 30(10),1198-1210. doi:10.1016/j.childyouth.2008.03.005

Schein, E. (2010). Organizational culture and leadership (4th ed.). Hoboken, NJ: Jossey-Bass.

Sekera, J. (2008). Komunitní systém v resocializačních zařizeních pro adolescenty I. (Mezilidské vztahy v resocializačních zařizenich pro adolescenty) [Community system in resocialisation centres for adolescents 1 (Interpersonal relations in resocialisation centres for adolescents)]. Ostrava, Czech Republic: Faculty of Education, University of Ostrava.

Shaw, T. (2007). Historical abuse systemic review: Residential schools and children's homes in Scotland 1950 to 1955. Edinburgh, UK: The Scottish Government.

Škoviera, A. (2011). Prevýchova. Úvod do teórie a praxe [Re-education: Introduction to the theory and practice]. Bratislava, Slovakia: FICE. 
International Journal of Child, Youth and Family Studies (2018) 9(2): 86-108

Škoviera A. (2014). Iné deti, iný život, iná kultúra. Kultúra a klíma v prevýchovných zariadeniach [Different children, different life, different culture. Culture and climate in reeducation facilities]. In Zborník z konferencie EDUCOM 2014, Education - Community, Edukačné prostredie a kultúra [Proceedings of EDUCOM 2014, Education - Community, Educational Environment, and Culture], 2014 December, University of St. Cyril and Methodius, Trnava, Slovakia.

Škoviera, A., \& Pukančík, M. (2012). Kultúra špeciálnych výchovných zariadení [Culture of special educational facilities]. In I. Lukšík (Ed.), Kultúra škôl a výchovných zariadení [School culture and culture of residential care facilities]. Bratislava, Slovakia: Comenius University.

Stein, M., \& Dixon, J. (2007). Young people leaving care in Scotland. European Journal of Social Work, 9(4), 407-423. doi:10.1080/13691450600958460

Stein, M., Pinkerton, J., \& Kelleher, J. (2010). Young people leaving care in England, Northern Ireland, and Ireland. European Journal of Social Work, 3(3), 235-246. doi:10.1080/714052827

Strauss, A. (1987). Qualitative analysis for social sciences. Cambridge, UK: Cambridge University.

Strauss, A. L., \& Corbin, J. (1999). Základy kvalitativního výzkumu: Postupy a techniky metody zakotvené teorie [Basics of qualitative research: Techniques and procedures for developing grounded theory]. Boskovice, Czech Republic: Albert.

Sulimani-Aidan, Y., Benbenishty, R., Dinisman, T., \& Zeira, A. (2013). Care leavers in Israel: What contributes to better adjustment to life after care? Journal of Social Services Research, 39, 704-718. doi:10.1080/01488376.2013.834283

Trice, H., \& Beyer, J. (1993). The culture of work organizations. Upper Saddle River, NJ: Prentice Hall.

Trout, A. L., Hagaman, J., Casey, K., Reid, R., \& Epstein, M. H. (2008). The academic status of children in out-of-home care: A review of the literature. Children and Youth Services Review, 30(9), 979-994. doi:10.1016/j.childyouth.2007.11.019

Ungar, M. (2005). Resilience among children in child welfare, corrections, mental health and educational settings: Recommendations for service. Child and Youth Care Forum, 34(6), 445-464. doi:10.1007/s10566-005-7756-6

Wade, J., \& Dixon, J. (2006). Making a home, finding a job: Investigating early housing and employment outcomes for young people leaving care. Child \& Family Social Work, 11, 199-208. doi:10.1111/j.1365-2206.2006.00428.x 
International Journal of Child, Youth and Family Studies (2018) 9(2): 86-108

Ward, H. (2009). Patterns of instability: Moves within the care system, their reasons, contexts and consequences. Children and Youth Services Review, 31(10), 1113-1118.

doi:10.1016/j.childyouth.2009.07.009

Wick, D., \& Bradshaw, P. (2002). Gendered value foundation that reproduce discrimination and inhibit organizational change. In I. Aaltio \& A. J. Mills (Eds.), Gender, identity and the culture of organization (pp. 137-159). London, UK: Routledge.

World Health Organisation. (1997). WHOQOL: Measuring quality of life. Geneva, Switzerland: World Health Organization, Division of Mental Health and Prevention of Substance Abuse. Retrieved from http://apps.who.int/iris/bitstream/10665/63482/1/WHO_MSA_MNH_PSF_97.4.pdf

Yoo, J., \& Brooks, D. (2005). The role of organizational variables in predicting service effectiveness: An analysis of a multilevel model. Research on Social Work Practice, 15(4), 267-277. doi:10.1177/1049731505275868 